\title{
Lugude vahel ja piiride taga. Välitööd konfliktses Kaukaasias
}

\author{
Aivar Jürgenson
}

Teesid: Artiklis vaadeldakse autori välitööandmete põhjal, kuidas ja miks on kujunenud ja toimivad piirid Abhaasia ja Gruusia vahel - nii füüsilised piirid kahe riigi vahel kui ka psühholoogilised barjäärid kahe maa kogukondade vahel. Peamiseks märksõnaks on sõda ja selle tagajärjed: aastatel 1992-1993 toimunud Gruusia-Abhaasia sõja tulemusena tekkis iseseisev Abhaasia riik, mida Gruusia ei tunnusta. Kahe maa kogukonnad elavad valdavalt üksteisest isoleeritult. Näidete varal autori kontaktidest Gruusia ja Abhaasia ajaloolaste ja etnoloogide ning Abhaasias elavate eestlastega vaadeldakse erinevate narratiivide mõju sealsete kogukondade meelsusele ja omavahelistele suhetele. Abhaasia ja Gruusia infovälja kõrval pööratakse tähelepanu ka Vene infovälja mõjule. Samuti sellele, kuidas mõjutavad erinevad infoväljad uurija ja uuritava kommunikatsiooni.

Märksõnad: Abhaasia, identiteet, Kaukaasia, meedia, sõda, välitööd 


\section{Sissejuhatus}

Esimest korda sattusin Abhaasiasse 1997. aastal. Sõjast Gruusia ja Abhaasia vahel oli möödas neli aastat. Suur osa maast seisis varemetes. Kõigepealt olid tekitanud purustusi pealetungivad grusiinid, muuseas põletati teadlikult ja tahtlikult maha Abhaasia Riiklik Keskarhiiv ja mõned teadusasutused, sest seal säilitati ajalugu, mis ei vastanud grusiinide Oma Loole. Hiljem tekitasid purustusi rekonkistat läbi viinud abhaasid ja nende liitlased Põhja-Kaukaasia mägilased. 1997. aastal olid purustused tänavapildis veel arusaadavad, kuid suuresti on pilt samasuguseks jäänud tänaseni. Suhhumi kesklinnas seisab ikka veel varemetes omaaegne valitsushoone, mille ees toimuvad näiteks võidupüha paraadid 30. septembril sel päeval, 1993. aastal, jõudis rekonkista lõpule, viimased gruusia üksused aeti üle Inguri jõe ja heisati piirile Abhaasia Vabariigi lipp. Kuuliaukude ja seinas mustavate tühjade aknaavadega hoone on jäetud teadlikult sõja mälestusmärgiks. Varemed peavad inimestel silme ees hoidma ülekohut, mida põhjustasid grusiinid, samas ka hoiatama, et ohud ei ole kuskile kadunud.

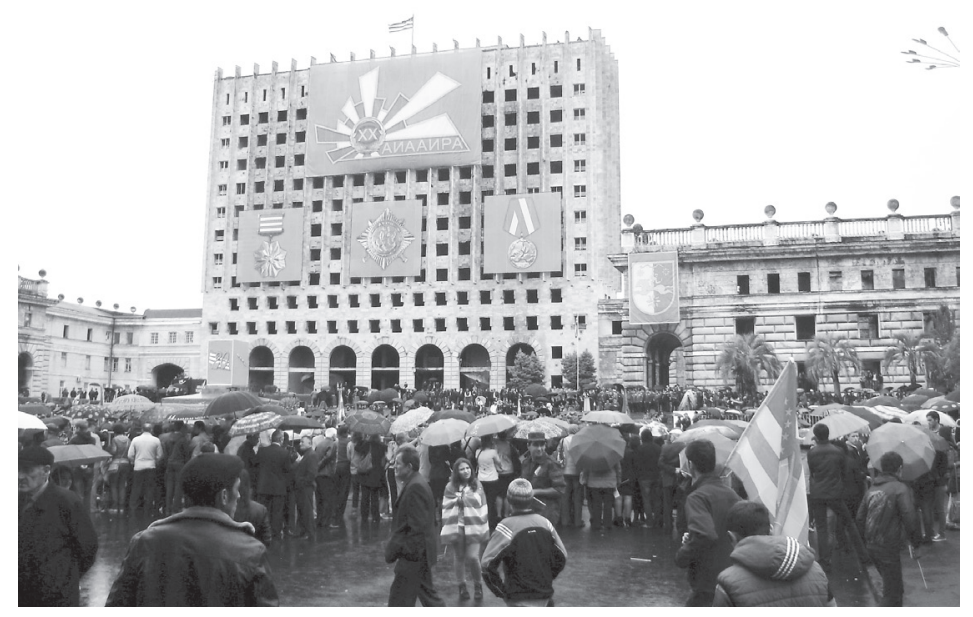

Võidupüha paraad Abhaasia endise valitsushoone ees 30. septembril 2013. Aivar Jürgensoni foto. 

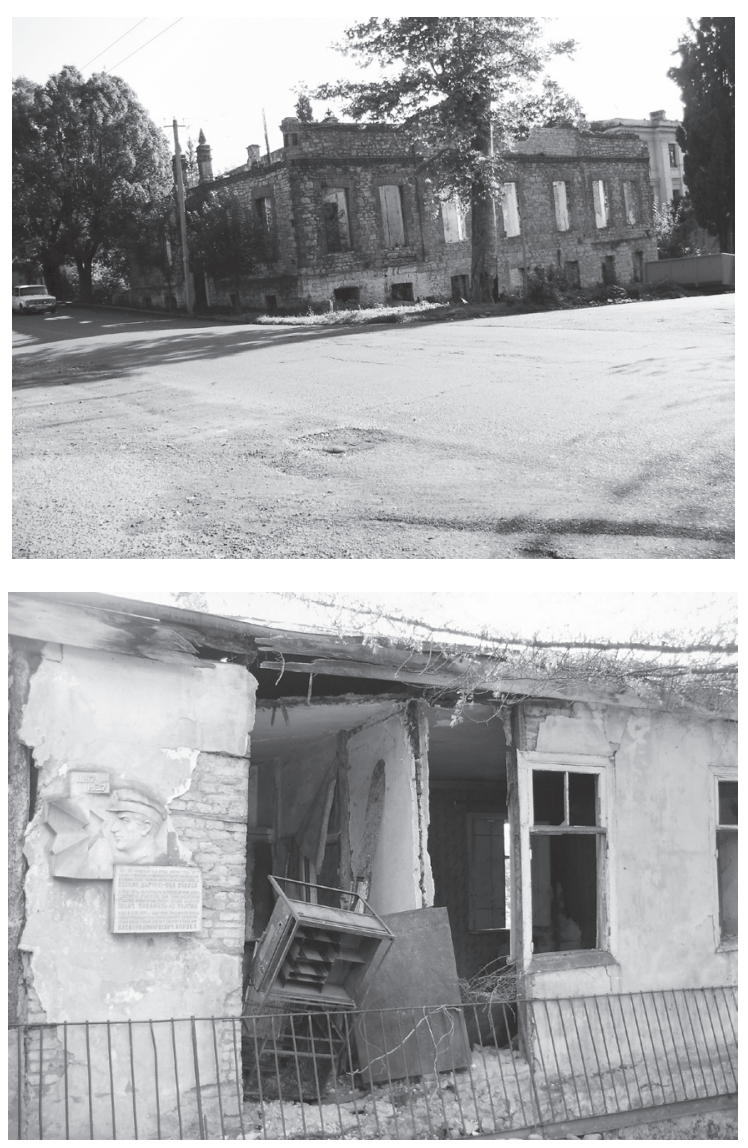

Sõja jäljed Suhhumis. Aivar Jürgensoni fotod.

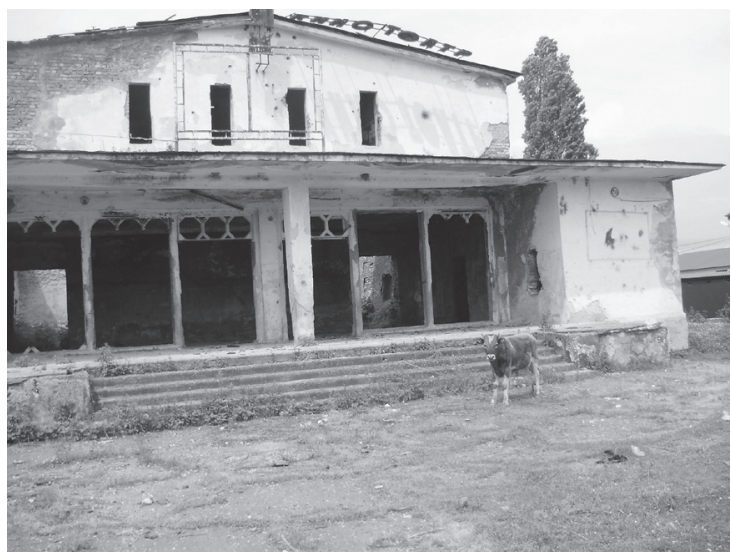


Sõda, millest on möödunud juba veerand sajandit, on Abhaasias endiselt oluline. Kohalikus meedias ei lasta mööda ühegi olulisema sõjasündmuse tähtpäeva. Nagu öeldud, tähistatakse igal aastal 30. septembril võidupüha - see on riiklik püha ja vaba päev, miitingule kogunevad kooliõpilased, sõjaveteranid ja teised, juubeliaastapäevadel toimuvad sõjaväeparaadid. Aga pühade kalendris on see kuupäev vaid n-ö sündmuste kese: paar päeva enne seda tähistatakse Suhhumis pealinna vabastamise aastapäeva, mis samuti toob tänavatele rahvahulgad. 2016. aastal tähistati seda tähtpäeva temaatilise kontserdiga rannapromenaadil, kus sõjalaulude vahele näidati suurelt ekraanilt lahingukaadreid. Kõnega esines Abhaasia Vabariigi president Raul Hadžimba.

Oktoobri algul jõutakse sõjasündmuste tähistamisega uuele ringile. Nädal pärast Suhhumi ja kogu Abhaasia vabastamise aastapäevi tähistatakse Gagra rajooni vabastamise aastapäeva - need sõjalised operatsioonid, mis oluliselt mõjutasid sõja käiku, toimusid aasta varem, s.t 1992. aastal. Kohalikus teleprogrammis kaiguvad seega nädal pärast võidupüha uuesti sõjalaulud, järjest võib näha intervjuusid sõjaveteranidega - kõlama jäetakse mõte, et igaüks

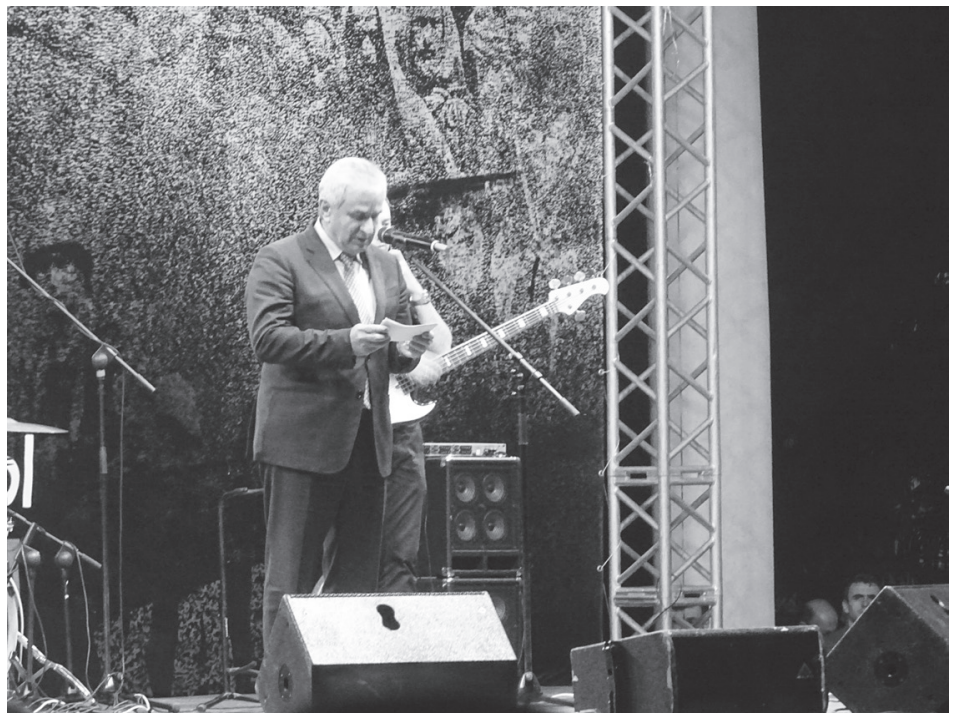

Abhaasia Vabariigi president Raul Hadžimba esinemas kõnega Suhhumi vabastamise aastapäeval 2016. Aivar Jürgensoni foto. 
võitles oma kodumaa eest. Sõjast on tehtud Abhaasia riikliku ja abhaasi etnilise identiteedi ankur - enda vabaks võitlemine Gruusia võimu alt tegi võimalikuks rahvusena püsimajäämise. Abhaasia peamagistraali serv on terve riigi ulatuses täis pikitud mitmesuguseid sõjamonumente. Sõda kujutatakse iseseisvuse nurgakivina ja sellest on saanud identiteedi kujundamise instrument. Seda kuvandit taastoodetakse pidevalt.
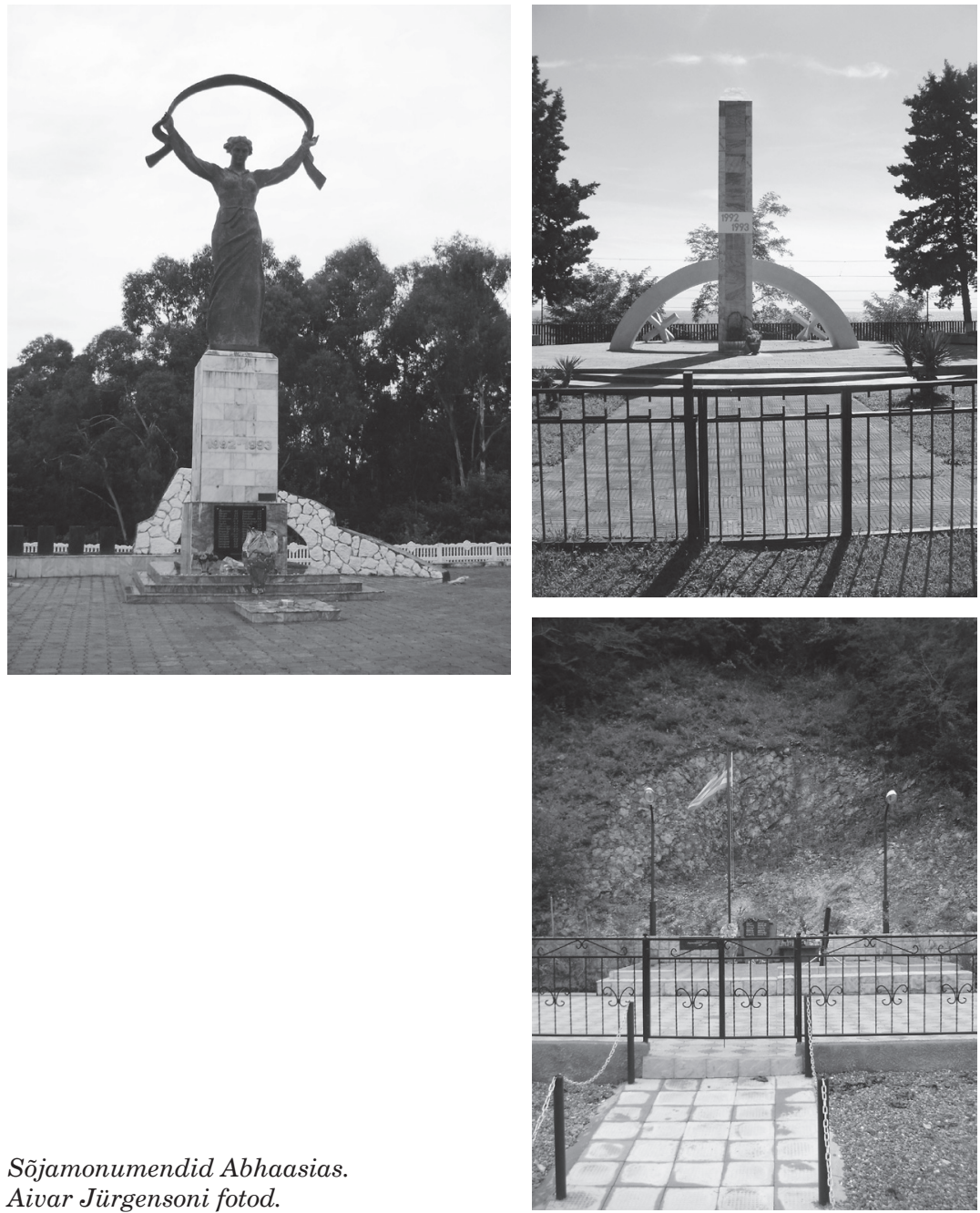

Aivar Jürgensoni fotod. 
Artiklis vaatlen oma välitöökogemuste najal, mismoodi on sõda ja erinevad lood sõjast mõjutanud ja mõjutavad inimeste ja gruppide vahelisi suhteid Abhaasias ja Gruusias. Vaatluse all on abhaasi-gruusia, abhaasi-vene, abhaasi-eesti, aga ka kodueestlaste ja Abhaasia eestlaste omavahelised suhted. Mööda ei saa minna ka minu kui Eestist saabunud etnoloogi ja kohalike omavaheliste suhete aspektidest. Samuti üritan vastata küsimusele, missugune mõju suhetele on erinevatel, sageli poliitiliselt laetud lugudel, neid lugusid vahendaval meedial ja laiemalt infoväljal. Esitan ka eneserefleksiivseid tähelepanekuid selle kohta, kuidas erinevatest poliitilistest kontekstidest sündinud lugude pingeväljas viibimine paneb kriitiliselt küsima "õigete" ja "valede" lugude olemuse ja mõju üle.

\section{Sõda ja selle tagajärjed}

Kuna Gruusia-Abhaasia sõda on sealsete inimeste teadvuses nii olulisel kohal, on sellest kujunenud justkui iseenesest keskne teema ka minu välitöödel. Olen kogunud Abhaasia eestlaste sõjamälestusi (vt Jürgenson 2016), kuid sõda tuleb paratamatult jutuks ka muudel teemadel kohalikega vesteldes. Sõja teema on aidanud mul kergemini informantidega kontakti luua. Kuuldes, mida ma tean ja arvan sõja sündmustest, või teada saades, keda ma tunnen sõjast kirjutanud Abhaasia teadlastest, on see aidanud luua usaldust minu kui võõra suhtes. Sõda on omal moel aidanud maandada ka tekkivaid pingeid, mis erinevate infoväljade mõjus elavate inimeste vahel paratamatult võivad tekkida. Kui näiteks tuleb jutuks Venemaa suurriiklik poliitika regioonis või ka globaalselt, olen sageli tajunud mittemõistmist enda ja oma informantide vahel. Pingete maandamiseks on olnud abi jutu juhtimisest Gruusia-Abhaasia sõjale - siin on meie seisukohad lähedasemad. Järgnevalt lühidalt sõjast ja selle tagamaadest.

Gruusia peab Abhaasiat enda põliseks territooriumiks, sellest kirjutatakse kategoorilisel toonil teadusüllitistes (näit Gamakharia 2011) ja toonitatakse poliitikute sõnavõttudes. Sellega seoses räägitakse Gruusia territoriaalsest terviklikkusest, kuigi on väga hästi teada, et Abhaasia liitmine Gruusiaga leidis tegelikult aset alles Nõukogude ajal. 1921. aastal, kui enamlased vallutasid Taga-Kaukaasia, moodustati eraldiseisev Abhaasia NSV, mis oli liidulepingus Gruusia NSV-ga. Formaalselt oli tegemist võrdsete partneritega, 1. aprillil 1925 võeti vastu Abhaasia NSV konstitut- 
sioon, mille 5. peatükk käsitles Abhaasiat suveräänse liiduvabariigina (Achugba 2011, 109-111). Siis aga liideti Abhaasia NSV 18. veebruaril 1931 Gruusia NSV-ga selle autonoomse vabariigina (Achugba 2011, 116-117; Companjen 2010, 189; Haindrava 2011, 7). Järgnes kohanimede massiivne grusiinistamine 1930. aastate teisel poolel, abhaasia latiniseeritud kirjaviisi asendamine gruusia kirjaviisiga 1937. aastal, abhaasi koolide üleviimine gruusia keelele 1945. aastal, lisaks massiline kolonisatsioon Gruusiast Abhaasiasse (Achugba 2006, 13-14; 2011, 120, 129, 132-133), mille tagajärjel jäid abhaasid oma põlisel kodumaal vähemusse. Kui veel 19. sajandi lõpul moodustasid abhaasid Abhaasias enamuse, siis 1989. aasta rahvaloenduse andmetel elas Abhaasias 525061 inimest, kellest $17,8 \%$ olid abhaasid, 45,7\% grusiinid (lisaks veel 14,6\% armeenlased, 14,3\% venelased) (Companjen 2010, 188; Haindrava 2011, 9). Nõukogude Liidu lagunemisprotsess 1980. aastate lõpul vallandas abhaaside avaliku vastuseisu grusiinidele ja taotlused Gruusiast lahku lüüa. 23. juulil 1992 võttis Abhaasia Ülemnõukogu vastu otsuse muuta Abhaasia ANSV 1978. aasta põhiseadust ja minna üle 1925. aasta põhiseadusele, mis käsitas Abhaasiat suveräänse liiduvabariigina (Lakoba 2001, 25; Achugba 2011, 171). Seepeale alustas Gruusia sõda: 14. augusti ööl 1992 sisenesid Gruusia väed Abhaasia territooriumile. Pealinn Suhhum vallutati 16. augustil, rünnakut toetas Abhaasia põhjaosast meredessant Tsandrõpši ${ }^{1}$ mille tagajärjel hõivati piirkond vastu Venemaa piiri. Abhaasia valitsus ja parlament evakueerusid Gudautasse, linna Suhhumist põhja pool. Sõda kestis ühtekokku üle aasta. Peamiselt põhjakaukaaslaste, sh eelkõige tšetšeenide abiga saavutasid abhaasid ülekaalu ja vabastasid Abhaasia 30. septembriks 1993. Kuna suurem osa Abhaasias elanud grusiinidest lahkus Abhaasiast, muutis sõda ka Abhaasia etnilis-demograafilist olukorda. Tänane rahvuslik koosseis Abhaasias on ametlikult järgmine: abhaase 122 000, armeenlasi 42 000, grusiine 47000 (http://www.ethno-kavkaz.narod. ru/rnabkhazia.html).

Sõda oli küll läbi, aga sellele järgnes Abhaasia majanduslik survestamine Gruusia ja Venemaa poolt: 1994. aastal sulgesid Gruusia ja Venemaa Abhaasia blokaadirõngasse, misjärel jäi Abhaasia välismaailmast isoleerituks. Blokaadi lõpetas Venemaa alles teise Tšetšeenia sõja algul 1999. aastal, kui olid halvenenud tema suhted Gruusiaga (Lakoba 2001, 100; Matveeva 2002, 421).

${ }^{1}$ Varem gruusiapäraselt Ganthiadi. 
Majandussanktsioonide mõjul, mida Gruusia rakendas Abhaasia vastu koos Venemaaga või ka eraldi, on Abhaasia häälestunud pigem veelgi enam Gruusia vastu. Samas on Gruusia ja Abhaasia suhteid mõjutanud Venemaa ja Gruusia suhete teravnemine. 2008. aasta augustisõjas toimus lahinguid ka Abhaasia pinnal, kus Venemaa vallutas senised puhvertsoonid Abhaasia-Gruusia piirialadel. Abhaasia, mis ametlikult sõjas ei osalenud, sai Gruusialt tagasi viimase osa oma territooriumist Kodori kurus. Seda on loetud Abhaasia Gruusiast täieliku eraldumise tähiseks (Francis 2011, 23). Venemaa tunnustas Abhaasia Vabariigi (nagu ka Lõuna-Osseetia) iseseisvust 26. augustil 2008. Oluline on ka see, et oktoobris 2008 lõppes SRÜ ja juunis 2009 ÜRO vaatlejate missioon regioonis. Vaakumi täitsid Vene üksused, mis andis Gruusiale ja ta liitlastele aluse hakata nimetama Abhaasiat ja Lõuna-Osseetiat "okupeeritud territooriumiteks" - sellekohase seaduse võttis Gruusia vastu 31. oktoobril 2008. Maist 2009 viibivad Abhaasias Venemaa piirivalvurid (Suhhov 2009).

Märke konfliktist Gruusiaga kohtab Abhaasias peaaegu kõikjal. Maa majanduslikku mahajäämust põhjendatakse suures osas tänaseni sõjaga. Sõda on tugevalt esil ka teaduses. Näiteks on omaette teadussuunana Abhaasias olemas konfliktoloogia. Linna peamises raamatupoes on esindatud korralik valik konfliktoloogia alast kirjandust. Peaaegu igal aastal toimub Abhaasias mõni teaduskonverents, mille pealkirjas esineb "konflikt" või "sõda". Veebilehel, millele on üles laaditud suur valik Abhaasia-teemalist teaduskirjandust, figureerib "ajaloo", "etnoloogia", "folkloristika" jt teadusvaldkondade kõrval ka "konfliktoloogia". ${ }^{2}$ On alustatud suurt allikapublikatsioonide projekti pealkirjaga "Gruusia-Abhaasia infosõja lehekülgi”, millest on seni ilmunud kaks mahukat köidet. ${ }^{3}$

\section{Piiride vahel ja taga. Välitöökogemustest mitte-eestlastega}

Eesti Vabariigi Välisministeeriumi kodulehelt võib lugeda soovitust Eesti kodanikel Gruusiasse reisimisel vältida sisenemist LõunaOsseetiasse ja Abhaasiasse, mis ei ole Gruusia keskvalitsuse

${ }^{2}$ Vt apsnyteka.org (09.02.2018).

${ }^{3}$ Страницы Грузино-Абхазской информационной войны (составители Т. А. Ачугба, Д. Т. Ачугба). Сухум: АбИГИ, 2015. 
kontrolli all. Eesti valitsus (nagu ka teised lääneriigid) on võtnud seisukoha mitte tunnustada Abhaasia iseseisvust ja peab Abhaasiat de jure Gruusia territooriumiks. ${ }^{4}$

Kui saabud Eestist, mille head suhted Gruusiaga on Abhaasias üldjoontes teada, ei maksa oodata, et sind automaatselt kauaoodatud sõbrana koheldakse. Abhaasias teatakse, et 2008. aasta Vene-Gruusia sõja ajal tegi Eesti president Toomas H. Ilves koos ametivendadega Lätist ja Poolast toetusvisiidi Mikheil Saakašvilile Tbilisisse. Seetõttu peab Eesti kodanik, kes saabub Abhaasiasse, arvestama võimalusega, et temalt hakatakse aru pärima Eesti Vabariigi välispoliitika teemadel. Ja mitte tingimata sõbralikul toonil. Probleemid võivad alata juba piiril. Gruusia-Abhaasia piiri, mis jookseb suuremas osas mööda Inguri jõge, valvavad ühel pool grusiinid, teisel pool aga nii Abhaasia kui ka Vene piirivalvurid. Gruusia-poolsel piiril paikneb vaid üks kabiin, milles istuv ametnik tegeleb dokumentide kontrolliga. Sealt tuleb astuda jalgsi üle silla, mina olen piiri mitmeid kordi ületanud jalgrattaga. Autodele on piiriületusluba eraldatud väga piiratult. Veoteenust üle silla pakuvad ka hobu- ja eeslirakendid. Abhaasia poolel ääristab piiripunkti okastraadiga tara, mis moodustab kitsa koridori - seda mööda liiguvad piiriületajad jalgsi ühest kontrollpunktist järgmisse. Neid punkte on piiril mitu: esimeses kontrollib Abhaasia piirivalvur, et sisenejal oleksid pass ja Abhaasia Välisministeeriumist saadud sissesõiduluba. Järgmises punktis, milleni liigutakse mööda okastraadistatud tunnelit, toimub dokumentide kontroll. Seal võib kohata nii Abhaasia piirivalvureid kui ka Vene FSB mundrikandjaid. ${ }^{5}$ Sellest punktist võidakse siseneja kutsuda veel kolmandasse punkti, mis asub pisut eemal üle tee - seal on mind küsitletud sissesõidu eesmärkide kohta ja kontrollitud pagasit, samuti tuntud huvi minu võrgustike vastu Abhaasias. Üldjuhul möödub piiriületus valutult, kuid ette on tulnud ka huvitavaid intsidente. Kord 2013. aasta sügisel kontrolliti piiril põhjalikult mu reisikaaslase fotoaparaati, tunti huvi jäädvustatud piltide vastu, ja kuna need olid tehtud ühel varasemal välisreisil, tuli rääkida ka tollest reisist. 2015. aasta kevadel võttis Vene FSB-lane mu vastu korraliku sõnavalinguga.

${ }^{4}$ Info reisimise kohta vt http://www.vm.ee/et/riigid/gruusia?display=travel_ info (09.02.2018). Tänaseks (2018) on Abhaasia riiklikku suveräänsust tunnustanud Venemaa (2008), Nikaraagua (2008), Nauru (2008), Venezuela (2009), Süüria (2018).

${ }^{5}$ Maist 2009 viibivad Abhaasias Venemaa piirivalvurid (Suhhov i.a.). 


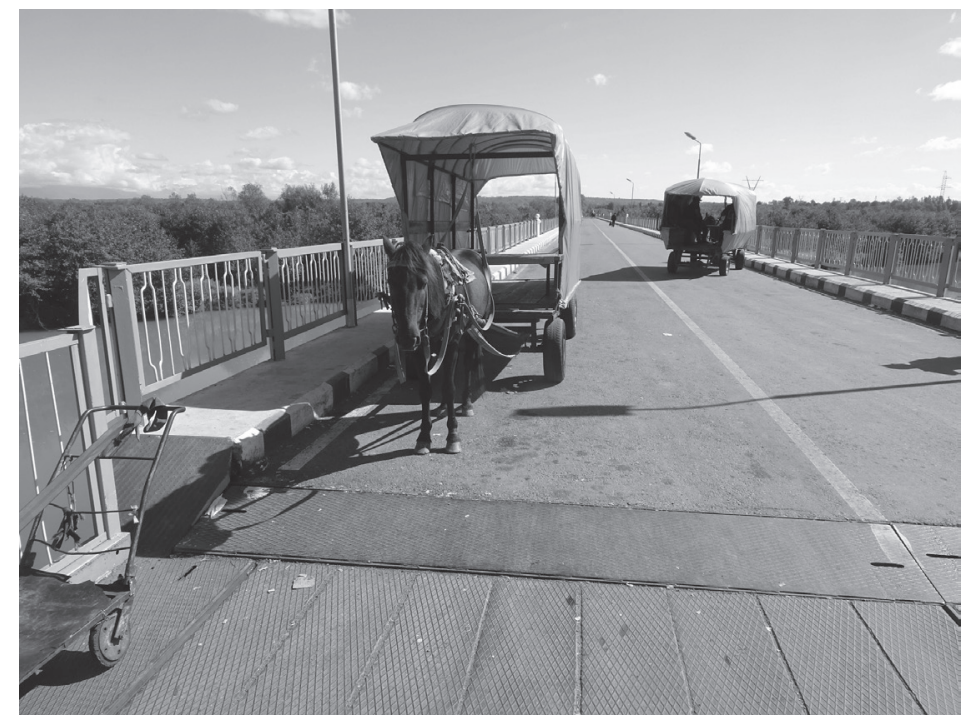

Abhaasia-Gruusia piiriületusel pakutakse veoteenust ka loomarakenditega. Aivar Jürgensoni foto.

Kuuldes, et tulen Eestist, käratas ta: "Aga mida see teie president jälle Venemaa kohta patras?" Olin olnud mõned nädalad Gruusias, Eestis toimunut polnud põhjalikumalt jälginud ja nii ei teadnud ma president Ilvese viimastest Twitteri-säutsudest midagi. Dokumentide kontroll kestis eriti pikalt.

Seevastu Gruusia-poolses piiripunktis möödub protseduur tavaliselt vahejuhtumiteta ja sujuvalt. 2016. aasta sügisel küsis noor piiriametnik siiski karmil ilmel: "Kas te teate, et lähete okupeeritud territooriumile?" No ma muidugi tean, et alates 2008. aastast on grusiinide retoorikasse ilmunud see uus väljend - "okupeeritud territoorium". Kuidas peaks see minu Abhaasiasse sisenemist aga mõjutama? Kas oodatakse, et minus ehk tekib süütunne ja ma peaksin oma visiidist loobuma, et olla solidaarne Gruusia territoriaalsete nõudmistega? Tuleb ka meeles pidada, et Gruusia käsitleb Abhaasiasse sisenemist teisest võimalikust piiripunktist, s.t Venemaaga külgnevalt piirilt Psou jõel, ebaseadusliku piiriületusena, mis on karistatav. 
Kui piiril olen pidanud tundma ennast eelkõige välismaalase või Eesti riigi kodanikuna, siis suheldes sealsete, nii Gruusia kui Abhaasia kolleegidega, olen lisaks sellele ka uurija staatuses. Sõda on jätkuvalt tundlik teema nii Gruusia kui Abhaasia teadlaste jaoks. 1992.-1993. aasta sõja algul, 22. augustil, kuulutas Gruusia Riiginõukogu esimees Eduard Ševardnadze Gruusias välja üldmobilisatsiooni, et kaitsta Gruusia "territoriaalset terviklikkust" (Achugba 2011, 166, 178; Avidzba 2008, 118). Sellest oli raske kõrvale hoida ka Abhaasia eestlastel. Seevastu Abhaasia poolel võideldi vabatahtlikena - võitlus maa vabastamise eest oli isiklike valikute küsimus (Broido 2010, 53). Selle kohta, et kohalikke eestlasi võitles nii abhaaside kui ka grusiinide poolel, olen andmeid kogunud Abhaasia eesti külades välitöid tehes. See, et eestlasi võitles sõjas nii grusiinide kui ka abhaaside leeris, on mõlema vaenupoole silmis häiriv fakt. 2013. aastal Suhhumis ühel konverentsil, mis taaskord oli sõjateemaline ja kandis pealkirja "Sõda ja rahu Kaukaasias", küsis minult üks sealne sõjast mitmeid käsitlusi kirjutanud etnoloog, et kas mul on andmeid eestlaste kohta, kes sõdisid Gruusia poolel. Temal selliseid andmeid ei olevat. Vastasin eitavalt ja nii see tookord ka oli. Kui mõne nädala pärast Tbilisisse jõudsin, kontakteerusin ka sealsete teemat uurinud Gruusia teadlastega. Seal ütles üks ajaloolane, et temal ei ole andmeid, et eestlased oleksid sõjas grusiinide vastu võidelnud. Et kui see nii oleks, "oleks see väga halb signaal”. Minu kõrvus kõlas see juba peaaegu ähvardusena. Mina oma andmeid ei avaldanud.

Gruusia ja Abhaasia vahel on ka normaalsed teadlaste vahelised suhted pigem haruldus. Abhaaside konverentsid mööduvad ilma grusiinidest osavõtjateta, grusiinide omad ilma abhaasideta. Üksteist ei külastata, mistõttu on aastatega tekkinud üksteisest võõristavaid kujutlusi. Kord Abhaasiast Tbilisisse jõudes külastasin seal asuvat Suhhumi Riiklikku Ülikooli, mis moodustati pärast sõda gruusia õppejõududest, kes Abhaasiast olid sõja eest põgenenud. Paarkümmend aastat ei olnud neist, kellega rääkisin, ükski Abhaasias käinud. Maad kujutati ette mahajäänud kolkana, kus grusiinide lahkumise järel on kõik allamäge veerenud. Kui paljastasin neile, et saabusin just Abhaasiast, tekitas see elevust: ühelt poolt tunti inimlikku huvi minu muljete vastu, teisalt tajusin, et minu visiiti Abhaasiasse peeti kahtlaseks ja sellest tulenevalt mind ennastki. Külastasin samas ka Tbilisi Ülikooli, kus üks ajaloolane pareeris mu arvamuse, et ka abhaasidel on õigus oma saatuse üle otsustada, 
väitega, et Eesti on ju tunnustanud Gruusia territoriaalset terviklikkust. Nendel kohtumistel Gruusia ajaloolastega tajusin, et usaldus minu vastu tulenes eelkõige minu Eesti kodaniku staatusest - see seostub Gruusias teatava kuvandiga. Tundsin, et minult oodatakse minu kodakondsusele vastavat poliitilist pooltevalikut.

Seevastu minu infiltreerumine Abhaasia ajaloolaste ja etnoloogide hulgas on toimunud edukalt, ehkki aste-astmelt. Esimestel kohtumistel aastal 2012 võeti mind ka seal vastu lihtsalt Eesti esindajana, kellelt eeldatakse Gruusia-meelsust. Mulle Gruusia ja grusiinid meeldivadki, kuigi nende agressiooni enda õiguste eest võitleva väikerahva vastu 1992.-1993. aasta sõjas ma heaks ei kiida. Neid oma seisukohti pole ma pidanud vajalikuks varjata ka Abhaasias. Järgmisel, 2013. aastal, esitleti mind Suhhumis toimunud konverentsil kui "ainsat eestlast, kes suhtub Abhaasiasse hästi". Veel mõni aasta hiljem, kui suhted on muutunud mõnede Abhaasia teadlastega juba üsna familiaarseks, nöögitakse mind sõbralikult "Eesti spiooniks". Niisiis olen ilmselt omaks võetud.

Abhaasia teadlased, kes on mu seisukohtadega kursis ja samas ka teavad, et sõidan Abhaasiasse tavaliselt läbi Gruusia, on väljendanud siirast muret minu julgeoleku pärast Gruusias. Arvatakse, et Gruusia kaitsepolitsei on kindlasti teadlik minu hoiakutest ning jälgib iga mu sammu Gruusias. Ise pole ma nende aastate jooksul Gruusiat politseiriigina tajunud ja tunnen seal end turvaliselt. Kuid needki abhaaside hirmud annavad tunnistust hermeetilisest müürist, mis seisab Abhaasia ja Gruusia ühiskondade kommunikatsiooni vahel. Hirm ja ettevaatlikkus kumab läbi sellest, kuidas üks Abhaasia etnoloog palus mul Tbilisis sealses parlamendi raamatukogus (tõsi, tema kasutas nõukogudeaegset nime Marxi raamatukogu - tähenduslik seegi) uurida, kuidas saaks sealt välja tellida 1850.-1860. aastate gruusia ajalehti. Etnoloog mõtles välja ka konspiratsioonitaktika: kui lähen raamatukokku, siis räägin, et mul on Eestis kolleeg, kelle abikaasa on grusiin ja tema sooviks neid materjale kasutada. Nii ma siis tegingi. Kohapeal selgus, et asjad on palju lihtsamad kui me alguses arvasime - ajalehed on digiteeritud ja internetis kõigile kättesaadavad. Võisin oma Abhaasia kolleegile edastada olulise informatsiooni ilma erilise vaevata, ühtlasi sain rikkamaks näite võrra hirmude ja usaldamatuse kohta, mida naabermaade kogukonnad üksteise suhtes tunnevad.

Abhaasia teadlaste suhtumine Eestisse on vaatamata Eesti ja Gruusia headele suhetele siiski valdavalt positiivne. Leitakse, et 
eestlased on edukad oma keeleseaduse rakendamisega ja meie kogemustest soovitakse õppida. Teadlaste palvel olen saatnud neile Eesti seaduste venekeelseid tõlkeid ja pole võimatu, et neist tõesti eeskuju võetakse - mõnedki mu tuttavad teadlased on Abhaasias ühtlasi poliitikud. Abhaasia keeleline situatsioon erineb siiski tuntavalt Eesti omast: kuigi ametlik riigikeel on abhaasi keel, kasutatakse ametkondlikus ja eriti olmetasandi suhtluses suurte muukeelsete kogukondade (armeenlased, grusiinid, venelased jne) olemasolu tõttu paralleelselt ka vene keelt, mille mõju rahvuslike teadlaste meelehärmiks on pigem kasvav kui kahanev.

Veel üks näide selle kohta, et suhtumine Eestisse on Abhaasia teadlaste seas pigem positiivne, ühtlasi ka selle kohta, et vähemalt osaliselt seostub see Abhaasia poliitilise isoleeritusega ja püüdlusega sellest välja murda. Juhtusin 2016. aasta sügisel Suhhumi ajal, mil paari päeva pärast pidi algama kohaliku humanitaaria suurkuju Śalva Inal-ipa mälestuskonverents. Kohe hakati mind agiteerima, et osaleksin konverentsil ettekandega. Loobusin, sest poleks nii kiiresti ettekannet valmis saanud. Üks ajaloolane aga jätkas lõõpivas toonis: me peaksime panema sind mitte niisama esinema, vaid plenaarettekannet pidama - küllap siis teie riik varsti tunnustab Abhaasia iseseisvust. Muidugi oli see mõeldud naljana, kuid Abhaasia mittetunnustamine lääneriikide poolt on kohapeal tegelikult valus teema: just Lääne ignorantsus on sundinud Abhaasiat otsima Gruusia vastu tuge Venemaalt, kes aga kasutab Abhaasia nõrkust ära enda geopoliitilistes huvides. ${ }^{6}$ Üha enam võtavad Abhaasia rahvuslikult meelestatud teadlased avalikkuses sõna sisse hiiliva Vene võimu vastu (näit Achugba 2014, 28).

\section{Etnoloogina Eestist Abhaasia eestlaste juures}

2008. aasta Vene-Gruusia sõja päevil tegi Eesti president koos oma Läti ja Poola ametikaaslastega Tbilisisse toetusvisiidi Gruusia presidendile Mikheil Saakašvilile. See Eesti toetusavaldus Gruusiale oli mu Abhaasias elavatele informantidele, kes tunnevad kohalikke

\footnotetext{
${ }^{6}$ Vene vägede sissetoomise leping sõlmiti 2009, pärast augustisõda, enne olid piiril puhvertsoonis ÜRO ja SRÜ rahuvalvajad. Abhaasid üritasid 1990. aastatel korduvalt saavutada diplomaatilist läbimurret lääne suunal, aga see ei õnnestunud ning viimane asjaolu kallutas neid Venemaas liitlast otsima.
} 
olusid Eesti poliitikutest võrreldamatult paremini, piinlik ja ebameeldiv. Nad jagavad seisukohta, et seda sõda alustas Gruusia, seetõttu tundub sealsetele inimestele mõistetamatu Eesti toetus agressorile. Eesti poliitikute toetust Saakašvilile kommenteerib üks eesti mees Suhhumist:

Ja räägivad mõnikord niisugust lolle asju, et... Kas sa ise üldse ei teagi, mis kus on? Ja vot suure suudega sääl lärmavad. No vot see ma ei saa aru. Hea küll, kui inimene on sääl [st Kaukaasias] olnud, vaatand, teab midagi, siis räägi! A ku sa oled midagit kuulnud või keegi sinu abi ütleb midagi nii-nii-nii-nii ja sa tema sõnad lähed ütled riigi eest ette. See on hoopis teine asi. Muidu suure suuga sääl: Saakašvili, Saakašvili! Nü̈̈d ameeriklased ka teda [Saakašvilit, keda praegune Gruusia valitsus peab kurjategijaks ja kellelt on võetud ka Gruusia kodakondsus] ei taha. Ja enda sõbrad lähvad kõik minema.

Eesti toetus Gruusiale häälestas paljusid Kaukaasia eestlasi Eestisse varasemast kriitilisemalt suhtuma. Kohalike eestlaste sõnul on Eesti riigi Gruusia-meelsus nende jalgealust õonestanud - muukeelsete elanike silmis on kohalikud eestlased justkui kollektiivselt vastutavad ka Eesti valitsuse sõnade ja tegude eest. Umbes seesama, mida ma olen ise Eesti kodanikuna korduvalt sealkandis kogenud.

On veel üks pikantne põhjus, miks sealsed eestlased on pidanud tundma ennast kollektiivselt süüdlastena. Gruusia-Abhaasia sõja kohta ringleb legend nn balti naissnaipritest - täpsuslaskuritest kuskilt Baltikumist, kes võitlesid 1992.-1993. aasta sõja ajal Gruusia armee ridades abhaaside vastu. Neist on kirjutatud ka Abhaasia sõja teaduslikes käsitlustes. ${ }^{7}$ Kuulujutud naissnaiprite kasutamisest on ringelnud ka seoses muude postsovetlike sõdadega: Tšetšeenias, Tadžikistanis, Ukrainas jm. Vene propaganda on nendega oma tegusid õigustanud. ${ }^{8}$ Kuna Abhaasias räägitakse küll Balti snaipritest, kuid nende rahvust pole täpsustatud, tunnevad Abhaasia eestlased end nende kuulduste valguses ebamugavalt - äkki olid nad eestlased? Sõnalisi süüdistusi on sealsetele eestlastele tõesti esitatud, seepärast täpsustavad eestlased intervjuudes snaipritest rääkides peaaegu alati, et need olid kas Lätist või Leedust, kuid mitte Eestist.

Abhaasia eestlastel on kohalike muukeelsete silmis justkui negatiivne renomee Eesti riigi - aga nähtavasti kogu Baltikumi ja laiemalt Lääne - poliitilise hoiaku tõttu, mis kaldub Gruusia-

${ }^{7}$ Sportlastest-snaipritest Baltikumist kirjutab näiteks ajaloolane Aslan Avidzba (2008, 137).

${ }^{8}$ Balti naissnaiprite kohta postsovetlikes sõdurilegendides vt Regamey 2017. 


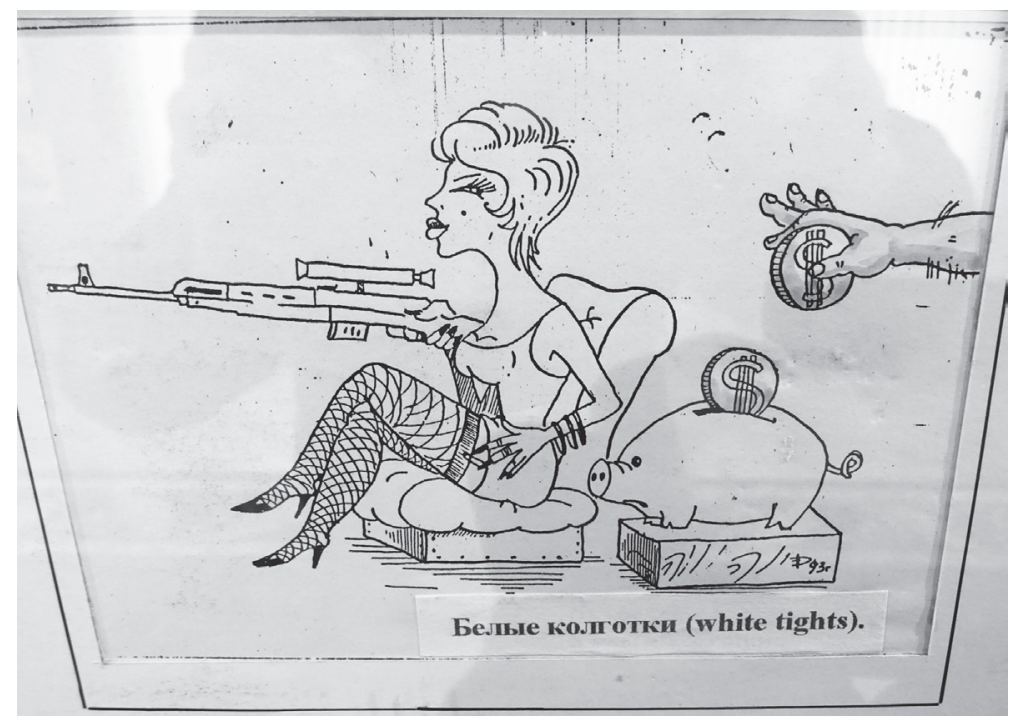

Karikatuur 2016. aastal Suhhumis Riiklikus V.T. Ardzinba nimelises sõjakuulsuse muuseumis toimunud 1992-1993. aasta sõjale pühendatud näituselt, kus peale fotode ja esemelise materjali olid väljas ka karikatuurid. Aivar Jürgensoni foto.

Abhaasia konfliktis Gruusia poole. Naine Gagrast: Siin eestlasi üldiselt ei armastata. Kõik teadsid, et eestlased [st Eesti riik] ei olnud Abhaasia, vaid Gruusia poolt.

Abhaasia eestlased tunnevad end sellega seoses justkui kahe tule vahel - ühelt poolt on solvav Eesti ametlik suhtumine Abhaasiasse kui iseseisvasse riiki, mida sealsed eestlased peavad oma kodumaaks. Teiselt poolt tajutakse kohalike poolt etnilise kuuluvuse alusel tõrjuvat hoiakut, mis seob Abhaasia eestlasi ebaõiglaselt Eesti riigi poliitiliste seisukohtadega.

Nii jutud arvatavatest balti naissnaipritest, president Ilvese toetusvisiit Tbilisisse kui ka paljud muud Eesti riigi toetusavaldused Gruusiale on olnud teemad, millest vestlustes kohalike eestlastega mööda ei pääse. Eestist saabunud etnoloog peab aru andma nii ühest, teisest kui kolmandast, poliitilised teemad kerkivad vestlustes sealsete eestlastega igal juhul üles. 
Minule kui Eestist saabunud etnoloogile on see intervjuusid läbi viies olnud nii plussiks kui ka miinuseks. Ühelt poolt esindan $\mathrm{n}$-ö vale poolt, mistõttu olen mõnede intervjueeritute poolt tajunud esialgu umbusaldust ja tõrjuvat suhtumist. Kuna ma Eestimaa eestlase staatusest kuidagi lahti poleks saanud, olen seda mõne isikuga vesteldes provotseerivalt ära kasutanud. Näiteks 1992.-1993. aasta sõjast rääkides hakkas üks esialgu tõrksust ilmutanud mees rääkima siis, kui olin talle öelnud, mida Eestis on sõjast kirjutatud - see tundus talle nii jalustrabavalt eksitav, et ta lihtsalt tundis endal kohustust mind valgustada ja mu eksiarvamusi kummutada (vt Jürgenson 2016, 124, 131).

Välitöödel olen aru saanud, et Abhaasia eestlased elavad täielikult Vene infoväljas, millel on oma mõju intervjuude läbiviimisele. Vene infoväljas leiab viimastel aastatel aset äge vastandumine Läänele. Nagu kirjutab Artemi Troitski, on kurja USA vihkamine Venemaal sisuliselt muutunud vaat et rahvuslikuks ideeks, selle peal töötab kogu propagandamasin (Troitski 2016, 4). Ameerika on ka paljude Abhaasia eestlaste meelest vallutamas maailma ja Venemaa presidenti Vladimir Putinit peetakse ainsaks jõuks, kes suudab sellele invasioonile vastu seista. Putini kuvand on rahva isa kuvand. Väga olulist rolli mängib siin televisioon, millel on jätkuvalt suur mõju inimeste hoiakute ja suhtumiste kujundamisele (Niitra 2016, 11). Olen ise näinud ja kogenud, et paljudes Abhaasia eestlaste kodudes mängib televiisor hommikust õhtuni, iga natukese aja tagant näeb eetris Putinit, kes julgustab, lohutab, hoolitseb. Ja seda kõige argisemal tasemel: umbes stiilis et kui mõnel külatädil läheb näiteks külmkapp rikki, otsitakse abi Putinilt, ja tema oskab televaatajate ees tädi julgustada nii, et julgustatuna tunnevad ennast miljonid. Just nii on pandud tööle Vene propagandamasin, et tõsta Putinigi reitinguid üha suurematesse kõrgustesse.

Tabavalt on suundumusi Vene meedias ja Putini esiletõstmist iseloomustanud Peter Pomerantsev. Ta toob näiteid, kuidas Putin on Ostankino kanalites vaatemängu keskmesse toodud, et rikastada autoritarismi reitingutega, diktatuuri dünaamikaga, kuidas on loodud virtuaalne distants Putini ja teiste poliitikute vahele (Pomerantsev 2013). See kõik on viinud usalduse Putini vastu kõrgustesse, mida vaevalt mõni teine poliitik Euroopas nautida saab. Vastanduses Läänele, mida seesama meedia ennastunustavalt produtseerib, on eeltöödeldud publikul hea ja turvaline toetuda Putini poliittehnoloogiliselt toekale käsivarrele. 
2016. aasta sügisel kohtusin Suhhumis naisega, kelle isa oli eestlane ja ema abhaasitar. Olin teda külastanud ka eelmisel aastal. Naine sündis 1940. aastatel sõjajärgses Eestis, kuhu tema vanemad olid elama asunud. Hiljem tuldi tagasi Abhaasiasse. Jutt keerles tavapäraselt Eesti ja eestlaste teemadel, poliitikast hoidsime eemale. Peagi saabus naisele külla tema õde ja tundus, et spetsiaalselt selleks, et uurida minu seisukohti globaalse poliitika küsimustes. Kohe hakkas sadama tuttavaid loosungeid Ameerika agressiivsusest ja Venemaa rahumeelsusest. Perenaine, kes seni oli minuga vesteldes poliitilistest teemadest hoidunud, sai õe saabumisel julgust juurde, hetkega muutus ka tema kehakeel: ta tõusis püsti, hakkas mööda tuba edasi-tagasi kõndima ja energiliselt kätega vehkima. Tema verbaalne sõnum oli, et niikaua, kui Venemaal on võimul Putin, elavad ka nemad Abhaasias hästi. Õde ja tema resoluutne poliitiline hoiak pakkus antud situatsioonis tuge ka perenaisele ilma õeta poleks ta poliitiliste teemadeni võib-olla jõudnudki. Kui õde lahkus, läksime sujuvalt enne katkenud vestluse juurde tagasi, nagu midagi poleks juhtunud.

Eesti riigi pooltevalikuid kritiseerivad Abhaasia eestlased üheselt ja karmilt. Nende teadvusse on juurdunud Venemaa kui suure venna kuvand, mistõttu tundub mõistetamatu, miks Eesti hoiab NATO ja Brüsseli poole. Näitena olgu esitatud tsitaat ühelt Salme küla mehelt, kes räägib Eesti poliitikutest: nad on marionetkad kes raha annab, selle järel nemad lähvad.

Või ühe Sulevi mehe sõnul:

Eestis üldse kõike räägitakse teistmoodi. Eesti on Ameerika all - mis Ameerika räägib, seda teie teate. A rohkem seal.. põle ühtki inimest, kes räägiks oigust. Vot see teie president - ta ei ole Eestimaalt? Teil seal kangesti kamandavad, kohalikke ühtegi ei ole. A neil inimestel on vaja teid? Põle vaja üldse! Nemad teevad, mis nendele öeldakse seal ja kõik - vot see on Eestimaa praegu. Mina sinna üldse minnagi ei taha!

Me võime küll aimata, et selliste seisukohtade taga on Vene pressi mõju, kuid Abhaasia-Gruusia konflikti kontekstis, mille hammasrataste vahel on ka sealsed eestlased, on neis tõdemustes tubli annus kibestumist.

Kuidas ma sellistes pingelistes olukordades olen käitunud? Venemaa ja Lääne vastasseisu põhjuseid olen üldiselt mõistnud erinevalt oma sealsetest informantidest, mistõttu olen sageli tundnud kiusatust vastu vaielda. Tulemuslik selline vaidlus aga üldjuhul ei ole, 
sest infoväljad, millest ühe ja teise poole argumendid pärinevad, on liialt erinevad. Õhku kerkinud pingete maandamiseks on olnud abi jutu juhtimisest mõnele muule teemale, näiteks Gruusia-Abhaasia sõjale, sest selle puhul on meie seisukohad olnud lähedased. Samas olen viimaste Abhaasia-reiside ajal ja järel eneserefleksiivselt tajunud, kuidas erinevatest poliitilistest kontekstidest sündinud lugude pingeväljas viibimine paneb kriitiliselt küsima "õigete" ja "valede" lugude olemuse ja mõju üle üldse. "Vale" looga pikka aega silmitsi seistes muutud tõe ja vale eristuse suhtes üha tundlikumaks. Sisemise filtri kude tiheneb ja paratamatult tulevad lõpuks esile kriitilised küsimused ka "õigele" loole. Aga sellest artikli lõpus.

Vestlustes kohalike eestlastega tuleb jutuks ka Abhaasia poliitiline olukord ja suhted abhaasidega. Kuna kohalikud eestlased elavad peamiselt Vene meedia infoväljas, jäävad abhaaside rahvuslikud taotlused neile sageli kaugeks. Suhhumis kuulen, et Abhaasia kohalikku telekanalit ei vaadata, selle asemel tarbitakse mitmeid Vene kanaleid. Vene piiri äärsetes Salmes ja Sulevis põhjendatakse Vene kanalite vaatamist sellega, et sinna Abhaasi TV lihtsalt ei levi. Kuid see pole kindlasti ainus põhjus.

Sealsete eestlaste Vene orientatsiooni taustaks ja ilmselt ka tagajärjeks on abhaasi rahvuslike taotluste mittemõistmine ja mittetunnustamine. Toon ühe näite. 2016. aasta sügisel arutati Abhaasias intensiivselt ühe riikliku fondi kava hakata maksma kolmanda lapse sünni eest lapsetoetust, mille summa ei olnud siis veel kokku lepitud, aga mis pidi olema vähemalt 100000 rubla. See on Abhaasia kontekstis suur raha. Toetuse eesmärk oli Abhaasias kriitilise demograafilise olukorra parandamine. Sõja tagajärjel vähenes rahvaarv üle kahe korra, suured perspektiivse põllumaaga territooriumid võsastuvad. Samal ajal on iive Abhaasias madal, suremus ja sündivus on tasakaalus, ajavahemikus 1999-2007 ületas suremus koguni sündivuse, hiljem on sündivus veidi suurenenud. Abhaasidel on teiste kohalike rahvastega võrreldes küll veidi kõrgem sündivus, kuid see on siiski kriitiliselt madal: 1,1\% (Hashba 2012 , 296). Nimetatud sünnitoetusi on fond nõus maksma aga vaid etnilistele abhaasidele. Opositsioon nimetas seda segregatsiooniks ja leidis, et kui on tegemist riikliku fondiga, tuleks sihtrühma laiendada kõikidele Abhaasia kodanikele. Eelnõu algatajate esimene vastuargument oli, et sõjas kandsid kõige suuremaid kaotusi abhaasid. Teine argument kõlab aga nativistlikult ja oli paljude 
kohalike meelest poliitiliselt ebakorrektne: väideti, et "me ei ela kosmopoliitses riigis - kui abhaasidel on siin halb, siis on kõikidel halb". ${ }^{9}$ Kui seda teemat kohalike eestlastega arutasin, leiti samuti, et taoline vahetegemine abhaaside ja mitteabhaaside vahel on segregatsioon. Vestlustes taoliste ja paljude teiste Abhaasias toimuvate sotsiaalsete või poliitiliste arengute üle jõuavad eestlased sageli abhaaside kui mägilaste nn metslaste stereotüüpi toetavate üldistusteni. Minul, kes ma suhtlen Abhaasia teadlastega, kellest valdaval osal on doktorikraad, on kummastav kuulata, kuidas mõned vähese haridusega eesti külaelanikud, aga ka linlased, peavad abhaase harimatuteks metslasteks, kes justkui on äsja mägedest alla tulnud riiki valitsema. Need tunnistused maa koloniaalsest minevikust on visad kaduma. Taolisi stereotüpiseeringuid põhjendab vähemalt osaliselt see, et Abhaasia eesti küladel on ajalooliselt olnud vähe kontakte maa põlisrahva abhaasidega. Eesti külad rajati 1880. aastatel paikadesse, kust abhaasidest põliselanikud olid rohkem kui kümme aastat varem minema aetud. Kolonisatsiooni jätkudes tulid eestlaste naabriteks armeenlased, grusiinid jt.

Suur osa eestlastest, kellega olen Abhaasia staatuse teemal vestelnud, leiavad, et Abhaasiale ja neile endile oleks kõige parem, kui Abhaasia ühineks Venemaaga. Olen Abhaasias suhelnud ka paljude mitte-abhaasidega, eelkõige armeenlaste ja kreeklastega - ka nende suust kuulsin soovist liituda Venemaaga. Abhaaside rahvuslikud püüdlused jäävad mitteabhaasidele sageli mõistetamatuks. Põhjendused on peamiselt majanduslikud - Abhaasia jääb elatustasemelt Venemaale alla ja see on argument nende silmis, kellele abhaaside rahvuslik projekt eriti korda ei lähe. Suurem osa Abhaasia kodanikest on ühtlasi Vene kodanikud. See tagab juurdepääsu Vene sotsiaalsüsteemile, sh pensionitele, mis on arvestatav sissetuleku allikas. Samas, kui ühelt abhaasi kolleegilt küsisin, mida arvata kuuldustest, et osa Abhaasia elanikest sooviksid ühineda Venemaaga, oli tema vastus kiire ja kirglik: "Kas me sellepärast pidasime maha sõja Gruusiaga, et nüüd ühineda Venemaaga?!"

Olen mõistnud, kui mitmetahuline võib olla see, mida me eemalt vaadates võime pealiskaudselt üldistades nimetada Veneorientatsiooniks. Kui mitteabhaasidel ulatub see kohati soovini ühineda Venemaaga, siis abhaasi rahvusliku intelligentsi esindajad peavad Venemaad oma liitlaseks eelkõige vaid selle tõttu, et muid võimalusi vastuseisus Gruusiaga lihtsalt keegi ei paku. Samas

${ }^{9}$ Tsitaat kohaliku televisiooni uudistesaatest 06.10.2016. 
suhtutakse kriitiliselt Venemaa ambitsioonidesse, mis geopoliitilisi sihte esmatähtsaks pidades ei jäta siirale abistamissoovile lihtsalt ruumi. Lääs toetab jätkuvalt Gruusia territoriaalset terviklikkust, mis tähendab Abhaasiat Gruusia koosseisus.

\section{Lõppsõna asemel: kellel on õigus?}

Inimene elab koos lugudega - ta loob lugusid, räägib neid edasi, tahab olla osa loost. Lugude alusel kujunevad piirid omade ja võõraste vahel. Carl Robert Jakobson andis meile loo seitsmesaja-aastasest orjaööst, mis on aidanud kujundada eesti rahvuslikku identiteeti. See lugu lõi piiri meie ja sakslaste-mõisnike vahele ja andis võimaluse tunda ühisosa teiste eestlastega. 19. sajandi teisel poolel kanti see lugu ka Vene tsaaririigi avarustesse, kus rajati eestlaste asundused. Tänaseni võib asundustes koguda lugusid kurjadest mõisnikest, kelle süül kas saadeti või tuldi ise võõrsile. 1944. aastal lahkus 70-80 000 eestlast Läände ja on kujundanud narratiivi, mis sisaldab episoode läbielamistest 1940. aastate alguse Eestis, põgenemisest, kannatustest, eesti kultuuri säilitamisest võõrsil ja vastandumisest venelastele-kommunistidele. Lood liidavad inimesi emotsionaalselt. Olen pagulasi ja nende järglasi intervjueerides kogunud neilt kirglikke põhjendusi, miks nad vihkavad venelasi (Jürgenson 2011, 109). Emotsioon liidab.

Abhaasia rahvusliku identiteedi ankruks on 1992.-1993. aasta sõda - see tegi võimalikuks jääda rahvusena püsima ja ehitada üles oma riik. Vastandus grusiinidega on osa identiteediloomest, mida vahendatakse koolihariduse ja meedia abil. Lugu sõjast ja vabadusest vahendatakse ka mitteabhaasidele, kuid nagu olen kogenud vestlustes sealsete eestlaste ja teiste mitteabhaasidega, ei suuda see lugu päriselt täita seatud eesmärke - kuigi vastandus Gruusiaga on üldiselt omaks võetud ka teiste etniliste gruppide seas, jäävad abhaasi rahvuslikud püüdlused mitteabhaasidele suuresti võõraks. Abhaasi lugu põrkub siin teise looga, milles jutustatakse Venemaa suurusest ja tema koloniaalsest missioonist, sh missioonist maailma päästa. Tänu Vene meediakanalite intensiivsele tarbimisele on see lugu mitteabhaaside seas abhaaside loost mõjusam ja atraktiivsem: kui grusiinid võivad küll olla kurjad ja ohtlikud, siis veel kurjemad ja ohtlikumad on ameeriklased. Õnneks on aga olemas keegi, kes suudab ameeriklastele vastu seista - see on Putin. Ja nii nagu on 
mulle mu informandid korduvalt mõista andnud, on see meie traagika Eestis, kui me sellest lihtsast tõest aru ei saa. Vene loo poole kallutab inimesi Abhaasias muidugi ka majanduslik argument, kuid ideoloogiline vastandus Läänele, mida produtseerib Vene meedia, annab inimestele selge orientiiri, kuidas maailmas toimuvat mõista.

Peter Pomerantsev maalib oma raamatus "Tõde ei ole olemas ja kõik on võimalik" tänapäeva Vene ühiskonnast pildi kui suurest tõsielusarjast, mida juhivad andekad poliittehnoloogid (vt Pomerantsev 2015, 78). Aleksandr Dugin järgib sama kujundit ja nimetab üht omaaegset juhtivat Vene poliittehnoloogi Kremli nukujuhiksdemiurgiks. Mängurlikult loodud Vene infoväljas on Dugini meelest ära määratud üleriigilise infoedastuse struktuur, mida meediakanalid jäigalt järgivad (Dugin 2013). Pomerantsev manab Venemaast pildi kui maatrikslikust lummutisest, kus "puudub juba igasugune side reaalsusega ning kus nukud kõnelevad hologrammidega ja mõlemad on veendunud, et on reaalsed" (Pomerantsev 2013; vrd Pomerantsev 2015, 256). Pomerantsev, kes on ise saanud hariduse ja meelsuse Läänest, toob Ostankino tegevusest hulgaliselt näiteid teleuudiste lavastamisest Venemaal ja sellest, kuidas luuakse Putini kui rahva isa ja päästja kuvandit (Pomerantsev 2015, 252-253, 255).

Abhaasia eestlased ja kodu-eestlased elavad suuresti erinevates infoväljades. Need väljad tekitavad maailmast erinevaid kujutisi, mistõttu ühe infovälja "elanik" võib teise infovälja "elanikku" pidada eksiteele aetuks. Olen seda välitöödel Abhaasias korduvalt kogenud, kuidas "tõde" ja "valet" peetakse omaseks vaid ühele infoväljale. Nii Lääne kui ka Vene infoväljad üritavad sisendada vastase agressiivsust ja samas tema lihtliikmete naiivsust. Kui ma ei kiida heaks Putini poliitikat, võin sealsete eestlaste silmis kergesti sattuda Lääne propaganda ohvri rolli. Pean samas tunnistama, et ise olen mitmetes olukordades surunud mõttes Vene propaganda ohvri rolli oma mitmeid sealseid informante.

Erinevate, tugevalt ideologiseeritud infoväljade pingeväljas viibinuna olen aga hakanud mõtisklema Eesti ja laiemalt Lääne infovälja mõju üle mu enda arvamuste ja hinnangute kujunemisele. Kas hullumeelsed maatriksid, millega eksitatakse Vene infovälja tarbijaid, on mujal oluliselt teistsugused? Viimasel ajal on ilmunud arvamusavaldusi, et infomullis ei ela üksnes Venemaa, vaid ka meie siin Eestis. Ka põhjuseid on sõnastatud (Niitra 2016, 11). Tiit Hennoste näeb meie peavoolumeedias valetamist, hämamist, 
kallutatust, hüsteeria üleskütmist (Hennoste 2017, 7). David Vseviov tõstab esile üliinnuka piiritaguse vaenlase otsimise tendentsi (Vseviov 2017, 2). Valdur Mikita leiab koguni: "Eesti propaganda ei ole sugugi vähem eemaletõukav kui vene või ameerika oma" (Mikita 2017, 4). BBC jt lääne meediakanalite vahelejäämised "tõeliste" sõjakaadrite lavastamisel Süürias ${ }^{10}$ on andnud vene irvhammastele hambusse ridamisi mahlaseid konte, millest vormida parastavaid anekdoote. ${ }^{11}$ Taolised näited annavad hea võimaluse mõtiskleda, kas pilt objektiivsest Lääne, sh Eesti, ja valelikust Vene meediast pole mitte liiga mustvalge. Väitele, et vaid Vene meedia on tänapäeval ideologiseeritud ja et vaid tema tegeleb vaenlasekuju loomisega ning et Lääne, sh Eesti meedia edastab üksnes neutraalset infot, pole lihtne põhjendust leida. Muidugi teeb Venemaa propagandat, kuid Vene propagandale vastupropagandaga vastates langeb Lääs samale tasemele, propagandasõja tasemele.

Käesoleva artikli teemapüstitusest jääb küll välja see, kuidas luuakse ühiskonnas sotsiaalseid representatsioone ja teadmisi, kuid kahtlemata on see oluline ka siinses kontekstis, kuivõrd võib mõjutada välitöö kulgu. Erinevad diskursused ristuvad inimestes ja inimestevahelises kommunikatsioonis. Ühiskonnas prevaleerivate diskursuste omaksvõtt ja nende dialoogi asetamine teistes ühiskondades prevaleerivate diskursustega võib luua eeldused konfliktsete olukordade tekkeks. Me võtame justkui "vabatahtlikult" omaks teatud diskursused, mis vahendavad meile teadmisi ja tõlgendusi ümbritsevast maailmast - need saavad meile omaseks, kuid me sageli ei teadvusta, kuidas ideologiseeritud meedial on kalduvus toetada narratiivi manipuleeritud tõlgendusega päriselust.

Abhaasias elavad ja Vene kanaleid tarbivad eestlased, kes kahtlemata on Putini poliittehnoloogide loodud maailma lummuses, ilmselt väga ei eksi, kui peavad Eestist saabunud külalisi Lääne

\footnotetext{
${ }^{10}$ Näiteks: https://bbcpanoramasavingsyriaschildren.wordpress.com/; http:// www.abc.net.au/news/2016-08-28/aleppo-maadi-barrel-bomb-syria/7792032; https://www.google.com/imgres?imgurl=https://tribwgntv.files.wordpress. com/2016/08/596252220-e1472405517579.jpg\%3Fquality\%3D85\%26str ip\%3Dall\&imgrefurl=http://wgntv.com/2016/08/28/bomb-hits-wake-forchildren-in-syria-at-least-16-dead/ $\& \mathrm{~h}=233 \& \mathrm{w}=411 \&$ tbnid $=\mathrm{jlV} 9 \mathrm{OB}$ odPiY $\mathrm{fM} \& \mathrm{tbnh}=169 \&$ tbnw $=298 \&$ usg $=\_$B 8 aoHlaLPBgliuCT0T0PAxa6jk0 $0=\& \mathrm{hl}$ =et-US\&docid=PGv_3WVbVHnzlM (29.11.2016).

11 Näiteks: http://news-front.info/2016/11/22/devochka-green-tea/ (29.11.2016).
} 
ideoloogilise meedia ohvriteks. Heitlus erinevate narratiivide vahel on tänase maailma reaalsus, mis võib välitöödel mõjutada ka uurija ja uuritava omavahelist suhtlust. Poliitilises kommunikatsioonis luuakse tänapäeval üha rohkem lugusid, milles tõde pole peamine. Kommunikatsiooni arsenalis on infokatked, millest osa on "päris", osa aga fiktsioon. Neist pannakse kokku lood ja neist omakorda suuremad lood. Lugude eesmärk on aga endine - siduda, eraldada, luua vaenlase-kujusid, kujundada kuuluvusi ja identiteete.

Artikkel on seotud projektiga IUT 31-6 "Eesti ajaloo rahvusülene raamistik: transkultuurilised põimingud, ülemaailmsed organisatsioonid ja piiriülene ränne (16.-21. saj.)”.

\section{Kirjandus}

Avidzba, Aslan 2008 = Авидзба, А. Ф. Отечественная война (19921993 ге.) Вопросы военно-политической истории Абхазии. Сухум (http://abkhazworld.com/aw/Pdf/Avidzba_A.F._Otechestvenn_aya_ vojna_d1992-1993.pdf-09.02.2018).

Achugba, Teimuraz 2006 = Ачугба, Т. А. К обоснованию статуса “ррузинских бежениев”. Сухум: Академия Наук Абхазии.

Achugba, Teimuraz 2011 = Ачугба, Т. А. История Абхазии в датах. Сухум (http://apsnyteka.org/file/Achugba_Istoriya_Abkhazii_v_datah.pdf 09.02.2018).

Achugba, Teimuraz 2014 = Ачугба, Т. А. Родину надо беречь. Сухум: Международный Центр Кавказоведения.

Achugba, Teimuraz \& Achugba, Daur 2015 = Ачугба, Т. А. \& Ачугба, Д. Т. (составители). Странищы Грузино-Абхазской инфбормационной войны. Сухум: АбИГИ.

Broido, Anna 2010 = Бройдо, А. 2010. Непокорный умирает стол: война 1992-1993 годов иэтнопсихология абхазов. Сухум: Научное издание.

Companjen, F. 2010. The war in South Ossetia. August 2008: Four Perspectives. - Companjen, Françoise \& Marácz, Lázló \& Versteegh, Lia (toim). Exploring the Caucasus in the 21st Century. Essays on Culture, History and Politics in a Dynamic Context. Amsterdam: Pallas Publications, 181-193.

Dugin, Aleksandr 2013. Goodbye, golden boy (http://www.vikerkaar.ee/ archives/312 - 09.02.2018).

Francis, Céline 2011. Conflict resolution and status. The Case of Georgia and Abkhazia (1989-2008). Brussels University Press (http://poli.vub. ac.be/publi/pdf-files/Conflict\%20Resolution\%20and\%20Status\%20 Publication\%20version\%202011.pdf - 09.02.2018). 
Gamakharia, Jemal (peatoim) 2011. Assays from the History of Georgia ABKHAZIA: from ancient days till present days. Tbilisi: Ministry of Education and Culture of Abkhazia, Institute of History and Ethnology of Iv. Javakhishvili.

Haindrava, Ivlian 2011. Perceptions of the Georgian-Abkhaz conflict before August 2008. - Gegeshidze, Archil \& Haindrava, Ivlian (toim). Transformation of the Georgian-Abkhaz conflict: rethinking the paradigm. London (http://www.c-r.org/sites/cr.org/files/Georgian\%20 Perspective_Transformation\%20of\%20Georgian\%3AAbkhaz\%20 Conflict_201102_ENG.pdf - 14.02.2018).

Hashba 2012 = Хашба, А. Ш. 2012. Этническое воспроизводство населения Абхазии (1922-2010 гг.). - Бгажба О. Х.(peatoim). Абхазоведение VII, 284-307. Сухум: АбИГИ.

Hennoste, Tiit 2017. Peavoolumeedia ja prillikivi. - Postimees AK, 28.01, 6-7 (https://arvamus.postimees.ee/3984309/tiit-hennostepeavoolumeedia-ja-prillikivi - 14.02.2018).

Jürgenson, Aivar 2011. Ladina rahva seas. Argentina ja sealsed eestlased. Tallinn: Argo.

Jürgenson, Aivar 2016. Gruusia-Abhaasia sõda Abhaasia eestlaste mälestustes. - Acta Historica Tallinnensia 22, 112-141 (doi: 10.3176/ hist.2016.1.06).

Lakoba, Stanislav 2001 = Лакоба, С. 2001. Абхазия-де-фбакто или Грузияde-юре? Sapporo: Hokkaido University (http://src-h.slav.hokudai. ac.jp/publictn/lakova/lakova-contents.html - 14.02.2018).

Matveeva, Anna 2002. Georgia: Peace Remains Elusive in Ethnic Patchwork. - van Tongeren, Paul \& van de Veen, Hans \& Verhoeven, Juliette (toim). Searching for Peace in Europe and Eurasia. London: Boulder, 416-444.

Mikita, Valdur 2017. Läänemeresoomlase viimane karje. - Postimees AK, 25.02, 4-5 (https://arvamus.postimees.ee/4021373/valdur-mikitalaanemeresoomlase-viimane-karje - 14.02.2018).

Niitra, Nils 2016. Ekspeaministri sissepoole elu Peterburis. - Postimees, 19.11, 10-11.

Pomerantsev, Peter 2013. Mõrad Kremli Matrixis. - Vikerkaar, september (http://www.vikerkaar.ee/archives/315 - 14.02.2018).

Pomerantsev, Peter 2015. Tõde ei ole olemas ja kõik on võimalik. Seiklused tänapäeva Venemaal. Tallinn: Tänapäev.

Regamey, Amandine 2017. Women-snipers from Chechnya to Ukraine: a Post Soviet War Legend. - Folklore: Electronic Journal of Folklore 69, 115-144 (doi: 10.7592/FEJF2017.69.regamey).

Suhhov, Ivan 2009. Abhaasia 2009. aasta presidendivalimised: mineviku osaline kordus. Rahvusvahelise Kaitseuuringute Keskuse analüüs. Tallinn: Rahvusvaheline Kaitseuuringute Keskus ( http://www.digar. ee/arhiiv/et/raamatud/50358 - 14.02.2018). 
Troitski, Artemi 2016. Putinismi diskreetne võlu. - Postimees AK, nr 42, $20.02,4$.

Vseviov, David 2017. Karikatuuride sõda. - Postimees AK, nr 412, 28.01, 2-3. Население Абхазии. ethno-kavkaz.narod.ru (http://www.ethno-kavkaz. narod.ru/rnabkhazia.html - 14.02.2018).

\section{Summary}

\section{Between stories and behind borders. Fieldwork in the conflict-ridden Caucasus}

Keywords: Abkhazia, Caucasus, fieldwork, identity, media, war

This article focusses on disagreements between Abkhazia and Georgia and the impact of such disagreements on the mentality of local communities. Data from the author's fieldwork is used to examine the way in which and the reasons why borders have been established and function between Abkhazia and Georgia - the physical borders between the two countries as well as mental barriers separating the communities therein. The principal keyword here is war and its related consequences. War in Abkhazia from 1992 to 1993 resulted in the independent country of Abkhazia, which is not recognised by Georgia. Georgia worked with and independently from Russia to set up an economic and information blockade against Abkhazia, which has turned Abkhazians even more against Georgia. The communities in the two countries are isolated from one another for the better part.

In the article I shall first examine the way my status as an Estonian citizen impacted my interactions both in Georgia and Abkhazia, including while crossing the border from Georgia to Abkhazia, since people in both countries are aware of the friendly attitude Estonia has towards Georgia. During meetings with Georgian historians I sensed that the trust they have towards me is primarily based on the fact that I am an Estonian citizen this conveys a particular image in Georgia - but their attitude was swiftly revised when I failed to live up to that image. I happen to disagree with the position that Georgia's claims against Abkhazia are justified and that Abkhazians should be refused the right to self-determination as an indigenous nation with a strong identity. In Abkhazia, I initially experienced the same kind of categorisation as an Estonian citizen that is expected to be pro-Georgia. Their attitude changed later, when they understood that all Estonian citizens do not necessarily oppose independent Abkhazia.

Even in interactions with Estonians who live in Abkhazia and typically oppose Georgia, I felt that I was being categorised as an Estonian citizen who is expected to be pro-Georgia. I was expected to provide reasons for the political stances of the Republic of Estonia. According to local Estonians, 
the pro-Georgia stance of Estonia has undermined their position. Locals who speak a different language consider local Estonians to be collectively responsible for the statements and actions of the Estonian government.

Estonians in Abkhazia generally inhabit an information field generated by Russia which opposes the West and has done so increasingly more over the last years. Hatred towards the evil USA has basically become something of a national idea in Russia and the driving force behind the entire propaganda machine. Estonians in Abkhazia mostly support the policies of Vladimir Putin, the president of Russia, and blame Estonia for being pro-West.

At the end of the article I will present examples of how ideology-driven and thus selective the media can be when covering events in Russia and the West alike, the role of the media and the entire field of information in general terms in developing and maintaining attitudes, and the way in which different information fields can affect the communication between the researcher and their subject. 


\section{PILDI SISSE MINEK. Artikleid välitööde alalt}

\section{Koostanud ja toimetanud EDA KALMRE}

http://www.folklore.ee/rl/pubte/ee/cf/pildisisse

ISBN 978-9949-586-93-6

DOI $10.7592 / \mathrm{TF} 11$

Tartu 2019

Trükis ilmunud:

Pildi sisse minek. Artikleid välitööde alalt.

Tänapäeva folkloorist 11. Tartu 2019

Sarja peatoimetaja: Eda Kalmre

Kogumiku koostaja ja toimetaja: Eda Kalmre

Keeletoimetaja: Asta Niinemets

Kaanekujundus: Artur Kuus

Küljendus: Diana Kahre

Veebiväljaanne: Diana Kahre

Trükitud Eesti Kultuurkapitali toetusel. Väljaande valmimine on seotud Euroopa Liidu Euroopa Regionaalarengu Fondi (Eesti-uuringute Tippkeskus) ja Eesti Haridus- ja Teadusministeeriumi uurimisprojektiga IUT 22-5. Väljaande valmimist on toetanud Akadeemiline Rahvaluule Selts.

E-raamatu valmimist toetas: EKKM14-344 Eesti keele, kultuuri ja folkloori kasutusalade laiendamine ja tutvustamine elektroonilistel infokandjatel.

(C) Eesti Kirjandusmuuseum 2019

(C) Eda Kalmre ja autorid

(C) Artur Kuus 